\title{
1. Guilds: brother[sister]hood, friendship, and mutual aid
}

The historical prototype for worker collectivism in the Western world is the guild model, which greatly influenced today's labor union structures. ${ }^{1}$ The guilds also exemplify early struggles with democracy, as well as attempts by the law to harness worker collectivism, both of which are still pertinent issues for labor unions today. The origins of the guild system are found in prehistory, spanning several millennia. Craft guilds were known to have existed in Mesopotamia almost one thousand years prior to the Code of Hammurabi (1754 BC), which itself had several sections devoted to craftsmen. ${ }^{2}$ The Gild of Stratford-upon-Avon, ${ }^{3}$ in response to the 1388 royal demand to prove its origins, stated that its beginnings were "in a time before memory." ${ }^{4}$ The account given here begins with the Roman collegia and then considers the early European guilds, revolving around the ethos of these organizations, their member

1 See generally George Howell, Trade Unionism New AND Old 1 (London 1900).

2 See David B. Weisberg, Guild Structure and Political Allegiance IN EARLY ACHAEMENID MESOPOTAMIA 52 (Yale 1967).

3 Terminology is complicated due to the time period covered as well as the different languages involved. For example, the modern term (and spelling) of "guild" has many antecedents. The historical accounts referring to guilds can use the following terms, in Latin: gildonia, confratriae, convivial, fraternitas, confranternitas, consortium, societas, solidatum, convivium, unio, conjuration, or collegia; in English: guild, gild, fraternity, confraternity, mystery, mistery, corporation, brotherhood, company, commonalty, livery company, trading corporation, municipal corporation; in Swedish: gilda, gille, skrå, and ambete; and in German: gilde, zeche, gaffel, genossenschaft, association, verien, einung, and zunft, to list a few of the variations.

${ }_{4}$ See Toulmin SMith, supra chap. 1 note 1 at 211: "[P]redicta gild est, et incept fuit, a tempore cuius contrarium memoria non existit." The 1389 response goes on to speak of the duties of the "bretheren and sisteren" consistently throughout the document. See also J. Malet LAmbert, Two Thousand YeARS of Gild Life-OR AN OUTLINE OF THE History AND DEVElopment of THE Gild System from Early Times, with Special Reference to Its AppliCATION TO TRADE AND INDUSTRY 1 (London 1891). 
and societal functions, and the laws which eventually governed them. The argument has been made that, in contrast to their more modern negative reputation as monopolists, guilds were actually the "first and original basis for the theory and practice of popular democratic government in Europe" and the first to give worker organizations a role in the polity. ${ }^{5}$

\section{THE GREEK AND ROMAN COLLEGIA}

The origins of collegia opficum as a form of craft guild are found in both ancient Greece and Rome, but the specifics have been lost. ${ }^{6}$ According to a legend preserved by Plutarch, Numa Pompilius, the second King of Rome, who reigned in the period 715-673 BC, divided the people of Rome by their trades and crafts into flautists, goldsmiths, carpenters, dyers, leatherworkers, curriers, blacksmiths, and potters, with all other occupations placed in one single organization. ${ }^{7}$ Artisans, as social groups freed from households, began to make their presence felt in about the sixth century BC. ${ }^{8}$ Associations of trades are mentioned in the laws of Solon (594 BC), which required fathers to teach their sons their trades. The Roman collegia were mentioned in the Twelve Tables (450 BC) as an imitation of a Greek model, perhaps the phratria $(\phi \alpha \tau \rho \hat{i} \alpha)$ that existed until about the second century BC. ${ }^{9}$ As a rule, the earlier Greek collegia were less formally organized, while the Roman collegia could have extremely complicated organizational structures. ${ }^{10}$ Greece later adopted the more formal Roman collegia.

5 See Antony Black, Guild \& State-European Political Thought From the Twelfth Century to the Present xvii (Transaction Publishers 2003).

6 See GunNar Hazelius, OM HANDTVERKSAMBETENA UNDER MEDELTIDEN 8 (Nordiska museet 1906).

7 See Plutarch (45-120 AD): THE RISE OF ROME: TWELVE LIVES BY Plutarch: Romulus, Numa, Publicola, Coriolanus, Camillus, Fabius Maximus, Marcellus, Aratus, Philopoemen, Titus Flamininus, Elder Cato, Aemilius Paullus, Numa chapter XVII (Christopher Pelling, Ian ScottKilvert, \& Jeffrey Tatum trans. Penguin 2013).

8 See Herbert Applebaum, The Concept of Work: Ancient, Medieval AND MODERN 44 (SUNY 1992).

9 The phratries owned property that could then provide an income to be used to support feasting and other cultic activities, as well as financial loans to members. See Phratries in OXFord Dictionary of THE Classical World (John Roberts ed. Oxford University Press 2007).

10 Much of this historical account has been taken from Esmée Myfanwy Thomas, Guilds of Craftsmen and Small Traders in the Ancient World (exclusive 
Collegia were controversial: at some times seen as seditious and rebellious, at others bundled with brigands. In 64 BC they were limited by law in response to a perceived Senate threat. Julius Caesar later adopted further restrictive measures. Emperor Augustus tightened controls in 7 BC through his lex Iulia de collegiis, requiring that any group of persons throughout Italy desirous of forming a craft guild had to seek authorization from the Roman government. Such privilege was only to be granted in consideration of the service rendered to the public by the grouping together of such individuals. ${ }^{11}$ At this point the collegia were corporate bodies, legal persons in their own right.

The collegia opficum as a type of craft guild was a society of individuals formed for their mutual advantage, with activities revolving around religion, burial rights, and their craft or trade. They built temples; held religious rites, feasts, and memorials; guarded tombs; set trade standards; and secured monopolies as well as the good will of politicians. They supported sick or unemployed members as well as widows. The members of these voluntary collegia were expected to pay dues and participate. Full members were on an equal basis with respect to submitting proposals and voting. The general assembly and officials constituted the collegia, and officials were appointed by the assembly of members. The collegia had their own charters that were enforced against their members through self-policing. The business holdings of a collegia could be extensive; for example, the bakers of Rome owned land in Europe and Africa, buildings in Rome, and warehouses in Portus. ${ }^{12}$

The freedom of membership that marked much of the Greek and Roman history of the collegia began to be severely restricted during the third century AD, and was totally abolished by the fourth century under the Theodosian Code. ${ }^{13}$ By granting state recognition, the collegia became part of the government machinery and were seen as indispensable for the production of the goods necessary for the Roman population. The occupations became synonymous with public responsibility, and no

of Egypt) from the Earliest Greek Times to the End of the 5th Century AD 75 (unpublished thesis, Oxford University, St. Anne's Society 1934).

11 See Suetonius: The Lives of the Twelve Caesars; An English Translation, Augmented With the BIOGRaphiEs of CONTEMPORARY StATESmen, Orators, Poets, And Other Associates, ch. XLII (J. Eugene Reed \& Alexander Thomson eds. 1889) Perseus Digital Library version available at perseus.tufts.edu.

12 See APPleBAUM, supra note 8 at 143.

13 See Cod. Theod. VI, 201.17 (399), VII 20, 1.12 § 3 (400). 
one could escape these obligations without committing an offense. ${ }^{14}$ Vocation was now a public duty regulated by the state. Membership in the collegia became mandatory for the period of one's own life and for the lives of any of one's children, with sons having no choice but to remain in the same collegia as fathers, and sons-in-law becoming "wedded to the calling of [the wife's] family."15 Freedom of movement was also limited, with craftsmen dragged back to the collegium and to their municipalities if they attempted to flee. Freedom of organization within the collegia was retained, however. Collective action such as strikes were few, but evidence does exist of such activity, in which craftsmen sought better terms and stricter enforcement of contracts with regards to payments, time limits, defaults, penalties, and prices. ${ }^{16}$

There is much debate about whether the Germanic and later European guilds stem from the Roman collegia. Roman collegia existed in Constantinople and Ravenna as late as $900 \mathrm{AD}$, and in Rome as late as 1030 AD. ${ }^{17}$ At a minimum, the Catholic Church maintained the structure of the collegia in certain European areas. Regardless of whether there is a direct connection as to origins, legal issues concerning the European trade guilds were analyzed during the Middle Ages by Canon lawyers in accordance with the collegia structures found in Roman law. Consequently, traceable Roman influence in the interpretation of the law regarding guilds, at least, can be discerned. ${ }^{18}$

14 See ApPlebaum, supra note 8 at 142.

15 See LAMBERT, supra note 4 at 13.

16 See APPlEBAUM, supra note 8 at 142.

17 The longevity of the Roman institution of collegia is outside the scope of this work. The Digest of Justinian, issued in 533 AD, includes collegia: see Justinian, Digest of Justinian Vol. 4 Chapter 22 of Book 47 (Alan Watson trans. PennPress 2009). The lifespan of the collegia is inextricably intertwined with the survival of the reach of the Roman Empire, or at least the reach of its institutional structures. For the argument that these existed well past $476 \mathrm{AD}$, see generally CHRIS WICKHAM, THE INHERITANCE OF ROME: ILLUMINATING THE DARK AGES 400-1000 (Penguin 2010). See also LAMBERT, supra note 4 at 52 for the argument of continuity past the fifth century AD with respect to collegia, as well as W.J. Ashley, SuRveYs Historic AND ECONOMIC 186 (London 1900) and HAZElius, supra note 6 at 13-15. But see Steven A. Epstein, An ECONOMiC AND Social History of Later Medieval Europe 112 (Cambridge University Press 2009) for an emphatic denial of any connection.

18 See LAMBERT, supra note 4 at 52 and ASHLEY, supra note 17 at 186. 


\section{THE EVOLUTION OF THE NORTHERN EUROPEAN GUILD SYSTEM}

The Northern European guild is often considered to have Germanic roots. The origins of the modern English term "guild," and its precursor "gild," are found in the Germanic/old Norse gilda and German gilde. In its first known use some time before $450 \mathrm{AD}$, gilda referred to a sacred banquet celebrating warrior feats, simultaneously confirming social solidarity through feasting and drinking. ${ }^{19}$ The oldest Swedish use of the word gilda is found on the Viking Bjälbo runestone dating from around 1000 $\mathrm{AD}$ : "Valiant men raised this stone in memory of Greipr, their gildbrother-Lófi carved these runes-Júti's son."20

At this point of time, a guild was any group bound together by ties of rites and friendship, offering mutual support to its members upon payment of entry fees (German geld, Swedish gäld). The Germanic guilds created this social organization not based on blood ties or even social status, but rather to provide a type of social security as constructed families. The ties were expressed as being those of brotherhood, sisterhood, and friendship. ${ }^{21}$ The members promised each other mutual aid and protection, providing burial services, for example, as seen with the Bjälbo runestone. Support for impoverished members or dependents of deceased members was eventually included, as was compensation at times for cases of fire or shipwreck, functioning as an early form of insurance. These early Germanic guilds were informal in that there were no legal requirements as to their formation, with the creation of a guild based on the intention of the members, not any official state consent. ${ }^{22}$

19 See BLACK, supra note 5 at 3 . There is even a specific term for this type of feasting: in Old English, gebeorscipe; in Swedish, gillesdrickningar.

20 The Old Swedish reads: "DrængiaR ræispu stæin pennsi æft Græip, gilda sinn, Lofi ræist runaR pessaR, Iuta sun"- -see Project Samnordisk Runtextdatabas Svensk-Rundata entry for Ög 64, available at nordiska.uu.se/forskn/ samnord.htm. There is a second runestone at Törnevalla, Sweden, also from around $1000 \mathrm{AD}$, that reads: "lveR/ØlveR ræistu stæin penns[a] æftiR Dræng, ØygæiRs(?) sun, gilda sinn [Alver/Ölver raised this stone in memory of Dräng, Ögers (?) son, his gild brother]", which speaks to there being a merchant guild (handelsgille) in that area at that time-see runinskrift Ög MÖLM1960:230.

21 In the Wallonian region of the Netherlands, southern Germany, and France, "brotherhood" (caritates) was used as a designation instead of the term "guild": see HAZELIUS, supra note 6 at 35.

22 See Otto von Gierke, Community in Historical Perspective 19 (Antony Black ed. reprint Cambridge 2002) (originally published in German in 1868 as DAS DEUTSCHE GENOSSENCHAFTSRECHT, vol. 1). 
These informal guilds became Christianized and ultimately Europeanized, institutionalized, and legalized during the Middle Ages. The earliest legal traces of guilds are found in the laws of King Ine of Wessex (688 to 726) banning turbulent proceedings at guild meetings. ${ }^{23}$ In 779 Charlemagne prohibited those guilds based on mutual membership oaths upon the penalty of scourging, nose-slitting, and banishment, as oaths of loyalty were to be made only to the sovereign. ${ }^{24}$ One of the earliest known English guilds was established during the reign of King Cnut (1016-35) by the Scandinavian thegn Orc, who founded Orcy's Gild among the frith-gildsmen of Abbotsbury.

An example of an early foreign guild in England is the Steelyard Merchants (Gilda Theutonicorum) of London, known as the Easterlings and later as part of the Hansa, settled prior to 967 and chartered in 1232. ${ }^{25}$ The Easterling guild had a council of 12 headed by an alderman, lived together in a collegiate fashion with a guild hall, and owned warehouses. ${ }^{26}$ The members had a common table and separate cells, and all men were required to remain unmarried. Marriage to an Englishwoman would result in the loss of privilege, later referred to as Hanse. This was a typical organization for the German guilds-both merchant and trade-abroad under the umbrella of the Hanseatic League. ${ }^{27}$

23 A man who slew a thief had to prove that the victim was a thief and not an associate (gegylda): see Lambert, supra note 4 at 43.

24 See BRENTANO, supra chap. 1 note 1 at 12.

25 See William Herbert (Librarian to the Corporation of London), THE History of THE TWElve GREAT LiVERY COMPANIES OF LONDON; PRINCIPALLY COMPILED FROM THEIR GRANTS AND RECORDS WITH AN HISTORICAL ESSAY AND ACCOUNTS OF EACH COMPANY, ITS ORIGIN, CONSTITUTION, GOVERNMENT, DRESS, CUSTOMS, HALLS, AND TRUST ESTATES AND CHARITIES, INCLUDING NOTICES AND ILLUSTRATION OF METROPOLITAN TRADE AND COMMERCE AS ORIGINALLY CONCENTRATED IN THOSE SOCIETIES, WITH ATTESTED COPIES AND TRANSLATIONS OF THE COMPANIES' CHARTERS, Vol. 110 (London 1837). See also Helen Zimmern, The Hansa Towns AND The Hanseatic LeAgue cxvi-cxxxu (Florence 1889).

26 The German Gild-Hall or Gildhalda Teutonicorum, the Gildhall of the Dutch, the Easterling's House, or des Hansee städtischen stallhoffes: see EDWARD P. Cheyney, An InTROduction to the Industrial AND SOCIAL History of ENGLAND 25 (New York 1916).

27 See GIERKE, supra note 22 at 66. 


\section{EARLY ENGLISH GUILDS}

An early Anglo-Saxon secular guild, Knighten Guilde, ${ }^{28}$ that existed at the time of King Edgar (959-75) was granted land in London "with the liberty of a Guilde for ever."29 Edward the Confessor (1042-66) granted this guild's first written charter. Several other early English guild statutes, ${ }^{30}$ including the tenth-century London Peace Gild ordinance, articulate the solidarity of these early guilds: "for friendship as well as for vengeance we shall remain united, come what may." ${ }^{11}$ Under the eleventh-century Gild at Cambridge statute, the members agreed to take on the patron saint of the guild, swear faithful brotherhood towards each other not only in religious but also in secular matters, support each other in sickness and death, and protect each other from criminals and from each other's own wrongdoings: "If all misdo, let all bear it; let all share the same lot." 32

The ethos of the guild was brotherhood (and in several cases sisterhood $\left.^{33}\right)$, friendship, and mutual aid among guild members. Members had equal voting rights, entailing that these guilds were very much based on a direct democracy model. The guilds could own property, had bylaws which they self-policed, and provided complaint and resolution procedures including their own courts, practicing equality among members. Different types of guilds existed during the Middle Ages, including social, religious, priests, merchant (gilda mercatoria), burgher, town, crafts, and peace (frith) guilds. ${ }^{34}$ Universities also began as guilds, with

28 Even here language and spelling are tricky, as this same guild is referred to during its history as the Enichten, Knigten, Cnughts, Cneughts, Anglische Cnuighten Gild, Cnithtegilda, Cnigtas Knytte gilda, Englisc Cnihtente gild, and Knighten gild.

29 See Herbert, supra note 25 at 6.

30 The terms "customs," "privileges," and "statutes" are loosely used at this time, mostly because they are so intertwined in medieval society. Custom refers to the unwritten law "time out of mind." Privileges were usually a sovereign's acknowledgement of a custom, while a statute was a written compilation of custom or privileges or both: see MACK WALKER, GERMAN HOME TOWNS, Community, State, AND General Estate 1648-1871, 35-37 (Cornell 1971).

31 See Marc Bloch, Feudal Society 420 (Routledge \& Kegan Paul Ltd. 1961).

32 See BRENTANO, supra chap. 1 note 1 at 5.

33 See Carole M. Nottingham, The London Middle English Guild Certificates of 1388-9 in Historical Introduction, 39 MEDIEVAL STUDIES 108, 111 (1995).

34 See HERBERT, supra note 25 at 3 . Guilds performed many functions, with respect to both trade and society. Herbert explains the guilds as one of the "first 
the colleges at Oxford and Cambridge comprising guilds of masters. ${ }^{35}$ The early merchant guilds included handicraftsmen among their members, but this membership ceased when the craft guilds began to be formed in their own right. ${ }^{36}$ The entire fabric of social, municipal, and trade life in the Middle Ages, with the exception of agriculture tied to the manor, was arguably kept within the circle of the guilds. ${ }^{37}$

The Rolls of the Exchequer during the reign of Henry I (1100-35) provide evidence of payments made for the right to form craft guilds, with guilds "amerced as adulterine" if founded without royal consent. ${ }^{38}$ The first known grant of a charter to a craft guild was by Henry II (1154-89) to the London weavers. King John (1199-1216) required all guilds to receive a royal charter of confirmation of their status (in exchange for a fee), and later royals repeated this requirement as a way to insure control over the guilds by granting and revoking privilegesand also as a source of revenue for the Crown, through the payments for such grants.

political, and one of the grand elementary parts of our constitution." One of the societal functions of the guilds originated from the Saxon custom of frankpledge. Saxon law ordained that "every freeman of fourteen years old should find sureties to keep the pease, or be committed, certain neighbours, consisting of ten families, entered into an association, and become bound to each other to produce him who committed an offence or to make satisfaction to the inured party." To effect this, members raised a sum of money among themselves that they put into a common stock. When one of the pledges committed an offence and fled, the other nine would pay satisfaction out of this stock. To better identify each other, as well as to ascertain whether any man was absent on unlawful business, the members would assemble at stated periods at a common table, where they ate and drank together. See Horne's Mirror of Justices, fourteenth century, book one, lib.i.c.de la veue des franc pleges, 7 Selden Society 1, vol. VII 42 (W.J. Whittaker and F.W. Maitland trans. 1893).

35 See Richard Hofstadter \& Walter Metzger, Academic Freedom in THE AGE OF THE College 4 (Columbia University Press 1961). Two models were created by the end of the twelfth century: the Bologna model based on guilds of students, and the Paris model based on guilds of the masters. Oxford and Cambridge followed the Paris model. One of the arguments made against the Swedish 1852 repeal of the universities' legal rights to self-policing (domsrätt) was that equals should be judged by equals, see Ernst Kallenberg, Akademisk jurisdiktion. Studenternas rättsliga undantagsställning, 2 STATSVETENSKAPLIG TIDSKRIFT 97-121, 105 (1906).

36 See HAZELIUS, supra note 6 at 37.

37 See LAMBERT, supra note 4 at 2.

38 See Stella Kramer, The English Craft Gilds And the GOVERNMENT-AN EXAMINATION OF THE ACCEPTED THEORY REGARDING THE DECAY OF THE ENGLISH CRAFT GUILDS 17 (Columbia University Press 1905). 
The growth in the guilds' sophistication and power at this time parallels the evolution of towns. ${ }^{39}$ In the twelfth century towns became new centers of power, commerce, opportunity, and culture, moving the focus of the economy away from manors, monasteries, and great fairs. ${ }^{40}$ Towns were often founded on charters and incorporated, either by the Crown, as was the case with London, or by a local noble having command of the land. Privileges were granted to towns under these charters in exchange, for example, for the payment of taxes or the supply of goods or military services. Citizens of the towns were free to pursue trades, giving rise to the German saying "the city makes you free."

Towns became centers of production and trade by the thirteenth century, with at least one merchant guild in every English town. These guilds included nearly all the principal town residents as members exercising the most important functions in trade, and also those closely bound to the municipal government. In some cases, the guilds founded the town. By this time, guilds were regularly also corporate legal bodies. Privileges were confirmed by royal or municipal charters which often now granted a monopoly and the regulation of all commercial interests within their domain, trade as well as geographic, as well as exemptions, for example, from paying trade tolls. Municipal positions were often held by guild members, and guilds were often mobilized for guard duty, militia and police functions, and public works. ${ }^{41}$

How thoroughly guild membership permeated the identity of their members as to their place in society can be seen from the following description taken from one guild's history:

Adam's eldest son was educated as a plowman, and his brother a Grassier [grazier]. The Fall of Man introduced the liberal sciences, divinity, law and physick; But tho' we had continued pure, as when we dropt from the creating Fingers of our Maker, Mechanick Arts had been necessary. In the Infancy of the World, before the Wranglings of Lawyers, the Sophistry of Philosophers, and turbulent factions of divines had debauched mankind, artists were in the highest repute. ${ }^{42}$

39 The peace guilds often became the foundation of towns, with guild duties becoming intertwined with civic duties. Eventually admission to a guild would be a requisite for admission to a city as a free citizen: see JACOB LUNDELL, OM HANDTVERKSSKRÅN, NÄRINGSFRIHET OCH ARBETS ORGANISATION 28 (Lund 1846).

40 See APPLEBAUM, supra note 8 at 230.

41 See APPLEBAUM, supra note 8 at 269.

42 See Alexander Pennecuik, Burgess and Guild-Brother of EdinBURGH, AN HISTORICAL ACCOUNT OF THE Blue Blanket, OR CRAFTS-MEN'S 
According to this guild version of history, artists practicing the crafts would have existed even if Adam and Eve had not fallen from grace.

At the height of their power, guilds could be seen as ruling most aspects of an individual member's life, both in terms of religion and of the mysteries of the craft. A principle of unanimity dominated craft guild decision-making, with members voting on their own statutes; electing their own officials, including the enforcers of the guild's statutes; and in some cases even electing their own courts. ${ }^{43}$ The rights of free association, addressing grievances, and providing remedies, as well as mutual assistance, were central. Masters were the official members of the craft guilds, but journeymen and apprentices were also governed by guild rules and had a voice in decision-making processes at this point in time. ${ }^{44}$ Advancing each other's interests and promoting the welfare of the members were the core aims of the early medieval guilds. ${ }^{45}$ The guild also regulated the external affairs of its members, competition within the trade, price and wage setting, and mutual restraint for the mutual good, as well as obtaining necessary legislation and political good will.

To modern eyes, the rules governing apprentices and journeymen at this point of time were very invasive on a personal level. A youth of 14 years of age would often leave his birth family entirely and move in with the master, receiving everything-clothing, substance, and housingfrom the master. An apprentice served for three years, as did a journeyman. ${ }^{46}$ The goal was to become master and a member in the craft, for without such membership the individual was barred from practicing the trade. The balance in numbers between masters, journeymen, and apprentices was vital to the economic and social health of the trade. If a master took too many journeymen and/or apprentices-too many being more potential masters than the craft could bear-the entire system would topple. Trained apprentices would not be able to become journeymen, and trained journeymen not able to become masters. This early regulation of the number of journeymen and apprentices prevented gluts in the crafts. When the interests of the masters, journeymen, and apprentices were no longer kept in balance, as seen in Chapter 2-with masters

BANNER, CONTAINING THE FUNDAMENTAL PRINCIPLES OF THE GOOD-TOWN, WITH THE POWERS AND PREROGATIVES OF THE CRAFTS OF EDINBURGH \& C. lii (Edinburgh 1722).

43 See Black, supra note 5 at 24.

44 See EPSTEIN, supra note 17 at 111.

45 See Howell, supra note 1 at 11.

46 See George Urwin, Industrial Organization in the SiXteEnTh AND Seventeenth Centuries 13 (London 1957). 
taking on more journeymen and apprentices than the craft could handlethis system began to disintegrate.

\section{GERMAN GILDE AND ZÜNFTE}

As with England, the Germanic notion of guilds, based on bonds of brotherhood, loyalty, and mutual aid, existed in fluid forms up to Charlemagne's ninth-century legislation. ${ }^{47}$ The early German guilds often had overlapping aims and religious, social, moral, political, and private law objectives, such as providing funerals, taking care of the poor and sick, providing funds for travel, and offering insurance against shipwreck, flood, fire, theft, or robbery. ${ }^{48}$ Evidence of German traders in England can be seen in the laws of London under the reign of Ethelred II in 978: "the people of the Emperor [Otto II of the Holy Roman Empire] have been judged worthy of the good laws, like to ourselves." 49

Charlemagne's legislation effected state intervention in these early, fluid corporative forms, with greater requirements regarding loyalty to the sovereign — confining guilds to single purposes within private law, in contrast to the freedom of guilds in England at this time. ${ }^{50}$ Early guilds include the Weavers' Guild in Mainz, evidenced by a letter dated 1099 from the Archbishop of Mainz to the guild,51 and the Charter of the Watermen of Worms, dating from 1106. The first record of a German miners' guild fund (Büchsen) is from the reign of Emperor Wenzell II of Bohemia in 1300. Miners' funds set up their own hospitals, and when a fatal accident occurred, a decent funeral was arranged and the widow provided with financial support. 52

Guilds, towns, and other corporative bodies had become so common and powerful that the German princes at the 1231 Diet of Worms expressed their marked disapproval of such organizations, perceived of as a clear threat to their own power. ${ }^{53}$ The establishment of town councils at the beginning of the thirteenth century gave landholders and merchants

\footnotetext{
47 See GIERKE, supra note 22 at 13.

48 Id. at 23.

49 See ZIMMERN, supra note 25 at $\mathrm{x}$.

50 See GIERKE, supra note 22 at xxiv and 28.

51 See HAZELIUS, supra note 6 at 38.

52 See K.P. Companje, R.H.M. Hendriks, K.F.E. Veraghtert, \& B.E.M. WidDERSHOVEN, TWO CENTURIES OF SOLIDARITY-GERMAN, BELGIAN AND DUTCH SOCIAL HEALTH CARE INSURANCE 1770-2008 35 (Amsterdam 2009).

53 See Zimmern, supra note 25 at $\mathrm{xxx}$.
} 
oligopolistic rights, often excluding the craftsmen. ${ }^{54}$ Vocational guilds began to form (Berufsgilden) in addition to the trade guilds (Gewerbsgilden) such as the Hansa. The London Steelyard became a major Hansa trade center, with privileges granted by English kings that such traders be treated as subjects and friends. ${ }^{55}$ Other ports, such as York, Bergen, Venice, Novgorod, and Stockholm, became Hansa cities. The Hansa associations of merchants became associations of cities, with Visby the German center of trade in the Baltic Sea, as blessed by Pope Honorius II. ${ }^{56}$

Craft guilds (Zünfte) began to emerge in the shadows of the merchant guilds during the thirteenth century, but were still relatively powerless. The different German guilds began to have explicit membership requirements in their charters, and persons who were not members of a trade guild in a city could not exercise their trade there (Bannmeile). ${ }^{57}$ Many guilds received privileges as official suppliers of certain services or products to a certain city. The guilds were also given jurisdiction to enforce these regulations within the trade.

The fluid form of the Hansa cities and merchants became affixed in a constitution adopted at the Cologne Confederation in 1367 in response to the actions of the Danish King Waldemar III Attardag, who had plundered Visby and threatened the Hansa herring trade in the Baltic Sea. The deputies of 77 Hansa towns declared war, and stated that the towns would be the enemies of the King of Denmark and "help one another faithfully." 58 Towns that were too weak to aid in battle could contribute monies. Those not joining the war were declared outside the Hanseatic League, entailing that no Hansa town, burgher, or merchant would buy or sell goods, allow entrance to their ports, or unload goods in their domains to those towns (and their citizens) outside the Hansa. When contacted by Waldemar, the towns individually responded: "The Hanseatic League having resolved on war, they must submit themselves to the general resolution which bound them all." 59 After prevailing in the war, the Hanseatic League received as concessions from Denmark two thirds of the revenues from Scania (southern Sweden), possession of Scania's strongholds, free passage at sea, and the right to veto any choice of Danish King for a period of 15 years.

\footnotetext{
54 See ASHLEY, supra note 17 at 192.

55 See ZimMERN, supra note 25 at xii.

56 Id. at $\mathrm{xv}$ and $\mathrm{xv}$ iii.

57 See HAZELIUS, supra note 6 at 93.

58 See Zimmern, supra note 25 at xliii.

59 Id. at xliv.
} 
Journeymen associations (Gesellenvereinigungen or Gesellenschaften), also referred to as brotherhoods (Brüderschaften), became more prevalent in the fourteenth century, based on similar structures and ideals as the guilds, but with a focus on better defending the journeymen's interests against masters as well as providing networks of self-help groups for young artisans on the tramp. These journeymen's associations began to take part in concerted collective action early on, for example with work stoppages in 1329 in Breslau and 1349 in Paris, and a ten-year work stoppage by the baker journeymen in Kolmar, supported by secondary actions throughout the Rhine Valley. The Kolmar dispute did not concern working conditions but rather the status and position of the journeymen in the church processional. ${ }^{60}$ By the fifteenth century, the journeymen's associations had an established autonomy within the guild, with the right to hold periodic meetings and have their own treasury and systems of mutual aid. Membership was obligatory, and all journeymen had to abide by the decisions of the association. Refusal to do so resulted in the journeyman being declared dishonorable, which entailed losing their job, being excluded from the association, and losing all rights to aid as well as tramping (discussed below). Letters would also be sent to the associations in other towns to prevent the individual from gaining work elsewhere. ${ }^{61}$

Religious guilds/fraternities were repressed in certain German areas during the Reformation in the 1520s. Many German cities were in favor of the Reformation, and much of the Protestant movement originated in the lower and middle strata of town citizens, including craftsmen and artisans, invoking a strong sense of community, brotherhood, and friendship, as well as equality of all believers. ${ }^{62}$ Certain parts of Germany abolished religious guilds/fraternities in 1524. The Peasant's Revolt in 1525 led to a tightening of state controls, similar to the Tudor legislation, hemming in the power of trade guilds. Just a few decades later, the Hansa began to lose many of their strongholds in the Baltic.

By the sixteenth century, the tramping system (Wanderjahre) was highly organized throughout the entire Holy Roman Empire. The Wanderjahr was an obligatory period of 4-5 years following a 3-4 year apprenticeship. Fairly detailed rituals were put into place regarding the tramping system, with a developed system of passports, lodgings, rules

60 See HAZELIUS, supra note 6 at 141.

61 See George S. Werner, Traveling Journeymen in Metternichian South Germany, 125 Proceedings in the American Philosophical Society No. 3 190-219, 211 (1981).

62 See BLACK, supra note 5 at 111. 
regarding welcome and work, and support in case of lack of work. ${ }^{63}$ Geschenkte Handwerke were the artisan circles in which aid was given to travelers and schenke was the cup of wine offered to travelers. ${ }^{64}$ The same tension seen in England between masters and journeymen began to manifest itself in the sixteenth century, with Imperial legislation passed to restrain the activities of journeymen-the Reformation of Good Order [Polizey] —in 1530, 1548, and 1577.65 Certain German states maintained a strong guild presence up to the nineteenth century. Guilds dominated not only production and trade, but also politics, social life, and ethical conduct, with home-town regimes based on a definition of honor that meant "domestic, civic and economic orderliness."66 The guilds maintained this equality by penalizing or excluding those who were seen as pushy, and by mutual agreement among the membership restraining expansion and promising security. ${ }^{67}$ This localization of power within German home towns gave rise to a self-sufficiency and collective individualism unique to northern Europe. One good example of this independence within collectivism is that community law (home-town custom) was considered by many in the home towns to break book law (imperial or church law). ${ }^{68}$ These home-town guild systems also provided extensive social welfare support to their members.

\section{SWEDISH GILLE AND SKRA}

Viking trade was extensively developed during the late eighth to mideleventh centuries, with routes starting in the Nordic countries and traveling out to the Middle East, Russia, Iceland, Greenland, and even North America. ${ }^{69}$ During this period, Swedish towns were neither large, nor populated, nor powerful and held no monopolies, a legacy that would go down the centuries. Every individual was basically free to do what was necessary to survive. ${ }^{70}$ Birka was the first significant Swedish

\footnotetext{
63 Robert A. LeEson, Travelling Brothers 158 (Granada 1979).

64 See WERNER, supra note 61 at 194.

65 Reformation of Good Order [Polizey] in 1530, Tit. 39, 1548, Tit. 36 \& 37

and 1577, Tit. $37 \& 38$, see WALKER, supra note 30 at 435 .

66 See BLACK, supra note 5 at 124 and WALKER, supra note 30 at 102.

67 See BLACK, supra note 5 at 125 and WALKER, supra note 30 at 134.

68 Id. at 75.

69 See generally, Kirsten A. SeAver, The LASt Vikings: The Epic Story OF THE GREAT NORSE VoYAGERS (Tauris 2014).

70 See LundelL, supra note 39 at 51.
} 
trading center in the late eighth century, followed by Sigtuna in the eleventh century. There is evidence of craft production in the latter. ${ }^{71}$

The Christianization of Sweden occurred between the eleventh and twelfth centuries, after which the Church became a powerful ally for the King as well as a significant patron of the crafts. ${ }^{72}$ As evidenced by the Bjälbo rune stone, Germanic guilds (gillena) existed in some form in Sweden by the eleventh century, the main four types being general guilds (allmänna gillen), priest guilds (prästgillen), merchant guilds (köpmannagillen), and craft guilds (hantverksgillen). The craft guilds never became as powerful as the merchant guilds. One reason given for this is that the Swedish guild system was strongly influenced by the Hansa trading system, with several Swedish cities part of the Hansa and given the accompanying influx of German traders and craftsmen, who often also held political power, particularly in Visby, Kalmar, and Stockholm. ${ }^{73}$ Visby was the most powerful Hansa city in the Baltic Sea by the twelfth century. ${ }^{74}$ Trade under the Hansa and Lübeck was in full swing by the mid-1350s, with textiles and linen the largest areas of import to Sweden. ${ }^{75}$

Craft guilds, or skrå,76 began to emerge in Sweden during the thirteenth century. Each craft often had two guild organizations in place:

71 See FOLKE LINDBERG, HANTVERK OCH SKRÅVÄSEN UNDER MEDELTID OCH ÄLDRE VASATID 38 (Prisma 1989).

72 See Michael NordBerg, I KUng Magnus TID, NORdEn Under Magnus ERIKSSON 1317-1374 191 (Norstedts 1995). Several facts complicate tracing the history of guilds in Sweden. Sweden as a huge land mass was sparsely populated and poor, the latter arguably up to the twentieth century. Pre-history in Sweden is seen as the period up to around $800 \mathrm{AD}$. A further complication is that many of the medieval documents were lost in the 1697 fire of the Stockholm royal castle, Three Crowns. The fire started in the archives, with up to 90 percent of the royal collection of medieval documents destroyed: see NORDBERG, supra at 11.

73 See SigFrID HANSSON, BLAND MÄSTARE, GESÄLLER OCH LÄRPOJKAR 8 (Norstedt \& söners förlag 1931); see also ZIMMERN, supra note 25 at xxxvii and LUNDELL, supra note 39 at 56.

74 See NORDBERG, supra note 72 at 262.

75 See LINDBERG, supra note 71 at 17 . Letters of privilege were issued to Lübeck by Birger Jarl in the thirteenth century and by Magnus Eriksson in 1336. By law, half of the mayors and councilmen in the Swedish cities in the fourteenth century were to be German, see Statdslagens konungsbalk, flock II. See also NORDBERG, supra note 72 at 122 .

76 The word skrå originally referred to a piece of leather, then to a parchment; later to the statute or charter written on parchment; then to the guild organization itself, becoming a type of shorthand designation for the business side of the organization, see HANSSON, supra note 73 at 7. 
the social guild, gille, and the craft guild, skrå. Many times the social guild was founded first and the professional master craft guild (ämbete) organized later, with individuals usually belonging to both. ${ }^{77}$ Journeymen and apprentices were part of this order, as seen from the charters. The journeymen association of saddlers (Bältare Svennernes skrå) has one of the oldest Swedish journeymen charters, dating from some time prior to 1437. ${ }^{78}$ The interactions between the different types of guilds, masters, journeymen, towns and guilds, Swedes, and Germans can be seen at the Falun mine, Stora Kopparberget (literally, in English, "the big copper mountain"). In 1344, King Magnus Eriksson confirmed Lübeck's ancient privileges in the mine. ${ }^{79}$ In 1347 masters and journeymen formed a guild there, which had the right to appoint 14 councilmen, of whom one would be the head of the mine and another a judge for all guild disputes. ${ }^{80} \mathrm{~A}$ peace guild, St. Georgs gillet vid Stora Kopparberget, was also formed there by the Germans. ${ }^{81}$

A marked distinction between the town (as often controlled by merchants, a mayor, and a council) and craftsmen existed historically in Sweden. Cities with their own laws and charters began to be founded in the thirteenth and fourteenth centuries, and often under the influence of either the German Hansa or the Danes. ${ }^{82}$ A rigid divide existed between those who lived in the country (landtmännen) and those who lived in towns or cities (stadsmännen), with different sets of laws in place for these two groups. The first national legislation was passed under the regency of Birger Jarl (1248-66) ${ }^{83}$ and the first legislative code encompassing both city and country dwellers was passed in 1350 under King Magnus Eriksson, the great-grandson of Birger Jarl. The 1350 Code was

\footnotetext{
77 See LINDBERG, supra note 71 at 73 and 74.

78 See G.E. KLEMMING, Samlingar utgifna av Svenska Fornskriftsällskapet—Skrå ordningar 3 (Stockholm 1856).

79 Operations at the Falun mine are believed to have begun in the Viking period, spanning a period of almost a millennium. The oldest written document as to the mine (then referred to as Tiskasjöberg) is a letter of privilege dated 1288 and signed by King Magnus Ladulås. The mine produced two thirds of the copper in the European market by the 1600s and was Sweden's largest employer, with more than one thousand workers. It was also its largest sole income source and a significant basis for its power: see generally David Dunér, Helvetet $i$ Falun, 3 POPUläR HistORIA 48-53 (2009).

80 See LUNDELL, supra note 39 at 53-54.

81 Id. citing J.H. SCHRÖDER, STATUTA CONVIVII A S. GeORgIO DicTi AD MAGNUM CUPRIMONTEM DALEKARLIAE (Uppsala 1833).

82 See LUNDELL, supra note 39 at 52.

83 See LindBerG, supra note 71 at 12.
} 
in effect until $1734 .^{84}$ Under it, every able-bodied adult had to either prove they had the means to be able to live for a year or be forced to work-a rule that remained in place until 1846.85 The crowns of Denmark, Norway, and Sweden were combined in 1389 under the personal rule of the Danish Queen Margareta Valdemarsdotter, daughterin-law to King Magnus Eriksson, and the Kalmar union was formed in 1397. The Kalmar union remained in place until Gustav Vasa broke free and was elected King of Sweden in 1523. The Hansa consequently dominated trade in the Baltic Sea and in much of Sweden, particularly Stockholm, until the sixteenth century.

The oldest known Swedish craft guild charter was for the Stockholm Tailors, issued by King Magnus Eriksson in 1356 and granting them a monopoly. ${ }^{86}$ Under that charter, no individual was to be admitted as a tailor unless first approved by a master after an apprenticeship, and then by the mayor and the organization's leaders. Several similar craft guild charters were issued in the fifteenth century, granting rights of selfpolicing, monopoly, meetings, elections, member fees, member limits, price setting, and sanctions, as well as rights of masters, journeymen, and apprentices. The charters also regulated processions, often concerning the guild's patron saint. Four main themes can be identified in the charters: economic regulation of the craft; illness and funeral insurance; selfpolicing of internal membership disputes through arbitration; and the social aspects of drinking and feasting together, or gillesdrycke. ${ }^{87}$

The importance of the guilds' social aspects in any of the countries discussed here cannot be overexaggerated. Brothers and sisters eating and drinking together in the common hall, with detailed ceremonies both for religious and professional reasons, often as markers of achievement such as becoming a journeyman, then a master, were deeply ingrained in the organizations. The best example of this can be seen from the Swedish 1501 Charter of the Goldsmiths' Guild. ${ }^{88}$ Upon the death of a goldsmith

84 See NORDBERG, supra note 72 at 119.

85 "Nu kan löskær man skeno göra, ok orkar ei til flriggia marka, fla skal han fangas sum för ær sakt ok haldas en manafla dag": see Magnus Erikssons landslag (1350). "Kan lösker man skeeno göra, oc orkar ey til III mark, tha scal han fangas oc haldas een maanadh": see King Kristoffer's landslag (1442) para. 37.

86 See LUNDELL, supra note 39 at 58.

87 See SunE Ambrosiani, FrÅn DE SVEnSKA SKRÅÄMBETENAS DAGAR 2 (Stockholm 1920).

88 One guild had no difficulty in creating a monopoly: the goldsmith's guild. This was most likely because the King wanted the goldsmith's guild to police the 
or his wife, every guild brother was required to "follow them to the grave" and any member who failed to do so, regardless of whether or not they had received notice of the funeral, was to be fined, without exception. ${ }^{89}$ Many charters also included the duty for members to contest any unfair funeral costs attributed to the deceased, and to hold masses. ${ }^{90}$ Even in death the cohesion of the guild was to be maintained.

On occasion, it was possible for the original social guild to be converted to a craft guild by the King or a high noble. The charters issued afterwards became more and more craft- as well as rule-based-a professionalization and legalization of the crafts, in fact. ${ }^{91}$ Granting monopolies to town guilds at this time and restricting those who lived outside the cities to only one trade was neither plausible, given the scarce population and extensive land mass, nor feasible, given the difficulties in enforcement. Neither were taxes assessed against the trade of handicrafts in the countryside at this stage, as seen from King Kristofer's country/ provincial law of 1442.92 Towns still did not constitute more than 5 percent of the Swedish population by the fifteenth century and did not dominate to the same degree seen in England because of the country's sparse population and the extensive geographic distance to be covered. ${ }^{93}$

The pattern of a career in the trades in Sweden basically followed that seen in England and Germany. An apprentice would serve their time in this role, become trained, receive a journeyman's certificate (gesällbrev), ${ }^{94}$ and enter the journeymen's association. The former apprentice

origins of precious metals and to ensure certain standards with respect to coinage: see JOHN KROON, GULDSMEDERNAS SKRÅ AV ÅR 1501 FAKSIMILTRYCK (Malmö 1959).

89 Id. at 124.

90 See LUNDELL, supra note 39 at 26.

91 See KLEMMING, supra note 78 at 5.

92 Kristofers landslag 1442 (Köpm B VII), part of the Växjöregulation of 1414.

93 The general population of Sweden at this time was about 500,000, with the nobility comprising fewer than two hundred families, only about ten of which were considered wealthier than farmers. About 2,500 individuals fell into the category of ecclesiastics including monasteries and cloisters, controlling 20 percent of the land and receiving a 10 percent tithe. Consequently, the demand for crafts was not very high during this period, as there was neither the population nor the wealth to engender any greater demand. This began to change after Gustav Vasa's reign: see LINDBERG, supra note 71 at 11 and 16.

94 Gesäll is the modern Swedish designation of "journeyman." Prior words included sven, knekt, and lönedräng: see KLEMMING, supra note 78 at 10. 
would most likely stay with the same master after becoming a journeyman, with the same room and board, but now with wages. In order for the journeyman to experience and hone different skills with different masters, based very much on the German model, a period of two to four years of tramping was expected. A very complex Swedish tramping system was created, with regulations as to board (two pillows), the persons to be contacted, and the amount and time of work to be performed. The journeymen's association also eventually provided illness and funeral insurance.

The three European systems examined in this chapter show similarities in the development of their guild systems as well as the internal self-regulation of the guilds. Though proffered as a description of the English guilds, the following is equally true of the systems created in Germany and Sweden, in that they all were

autonomous republics with their own employment, population and emigration policies and apparatus: their welfare system from orphan allowance to funeral benefit, their inner democracy, far more intricate and alive than the official democracy of the Parliament which excluded them; their own financial system, laws and customs, check points and passports. ${ }^{95}$

The guilds in this early period were pockets of democracy offering stability and support for their members in times of great social change.

95 See R.A. LeEson, United We Stand-An Illustrated account of Trade Union Emblems 7 (Adams \& Dart 1971). 